\title{
Metaphorical models and the translator's approach to scientific texts
}

\author{
Rita Temmerman \\ Erasmushogeschool Brussels \\ Hogeschool Antwerpen (HIVT)
}

\begin{abstract}
Indeed, the utility of theory-constitutive metaphor seems to lie largely in the fact that they provide a way to introduce terminology for features of the world whose existence seems probable, but many of whose fundamental properties have yet to be discovered. Theory constitutive metaphors, in other words, represent one strategy for the accommodation of language to as yet undiscovered causal features of the world. (Boyd 1979:364)
\end{abstract}

In this article we investigate the mechanisms behind the urge for better and new understanding. Our hypothesis is that these are generally related to and inspired by metaphorical reasoning. The existing cognitive model of a source domain of understanding is used to structure and categorise a target domain. The metaphorical model is an underlying schema which is not fully expressed propositionally and lexically. The traces and results of metaphorical thinking are in metaphorical lexicalisations. We challenge the principle of traditional Vienna school terminology theory which claims that because unambiguous communication is the ideal in scientific communication, it is preferable to replace a metaphorical term by its literal equivalent. We show how in the life sciences the gestalt-like metaphorical model which was at the basis of better understanding and new discovery continues to have an important role in didactic as well as in scientific texts which treat the same or related subjects. The discipline of terminology theory could work out guidelines for the description of metaphorical models starting from the metaphorical lexicalisations which are the traces which metaphorical thinking leaves in a language. Translators who are aware of the impact of metaphorical reasoning on lexicalisation in scientific language will develop the ability to distinguish between metaphorical models which are language and culture independent and those which are not.

The source and target domains of analogical thinking - which are at the basis of metaphorisation - were traced for this project in the domain of the life sciences. The traces of this analogical thinking are in the textual archives of the domain. The analogical thinking can be traced from the metaphorical lexicalisations present in the lexicon of a language and it can be brought to a conscious level and explicitly explained. Attempts have been made to get more insight into the inter-relatedness of metaphorisations occurring in the language of a particular domain of experience, i.e. to trace metaphorical cognitive models (Lakoff \& Johnson 1980; Lakoff 1987; Johnson 1987; Liebert 1992, 1995a,1995b,1996). 
In what follows we shall first define what we mean by metaphor (section 1.). Then, we claim that in contrast to what the traditional schools of terminology theory believe, metaphor research in special language is relevant (section 2.). In section 3. we show how the underlying metaphorical cognitive model $(\mathrm{CM})$ concerning the understanding of genetics is information. This CM has several sub-CMs like DNA IS A LANGUAGE (section 3.1.), DNA IS INFORMATION IN AN ATLAS OF MAPS (section 3.2.), DNA IS SOFTWARE (section 3.3.) and DNA IS A TAPE OF FILM (section 3.4.).

Apart from providing us with evidence showing the existence of a metaphorical CM and providing us with the data for the description of a systematic analysis of metaphorical neolexicalisations, the case study will also furnish evidence supporting the following two issues.

One, the claim of traditional terminology theory that it is better for the linguistic sign to be arbitrary ${ }^{1}$ instead of motivated in order to assure univocity and to avoid polysemy, has to be refuted. If cognition and language are seen as intertwined faculties, then a large number of linguistic signs that are structured in a metaphorical CM show systematicity and hence are motivated. This does not imply, however, that the development is predictable. Terminology theory might want to get more insight into how metaphorical CMs influence the process of categorisation and create some guidelines for their description (section 4.). Two, scientific translators in the field of the life sciences and in other disciplines need to be aware of underlying metaphorical thinking in the lexical development of the discipline they are translating (section 5.).

\section{A definition of metaphor}

Metaphor can be considered a multidimensional phenomenon. Whereas before, metaphor was thought to be either a deviant form of expression or a nonessential literary figure of speech, in recent decades metaphor has achieved a remarkable prominence in philosophy, psychology, linguistics and other cognitive sciences (Ortony 1979; Lakoff \& Johnson 1980; Paprotté \& Dirven 1985; Johnson 1987; Lakoff 1987; Kittay 1987; Gentner 1988; Way 1991; Indurkhya 1992; Liebert 1992).

The term 'metaphor' "is often used to refer to nonliteral comparisons that are novel and vivid and that convey ideas that are otherwise difficult to express" (Ortony 1975, in Gentner et al. 1988:171). As Lakoff \& Johnson (1980) have shown, metaphor is not a matter of language alone, rather "The essence of metaphor is understanding and experiencing one kind of thing in terms of another" (5). For our purpose of studying the role of metaphor in terminology theory we distinguished between lexeme metaphor, category metaphor and domain metaphor (Liebert 1995a; Temmerman 2000a) .

In studying the parole of the life sciences in texts written by field specialists we have been looking for linguistic expressions and lexicalisations 
which furnish proof of the image-schematic dimension of metaphor. We wanted to investigate the possible impact of the metaphorical cognitive model hypothesis on the theory of terminology and on how scientific translators might be trained to deal with metaphorical lexicalisation. Therefore we needed to start from what traditional terminology theory had to say on metaphor.

\section{Metaphor in traditional terminology theory}

In their first chapter of Metaphors we live by (1980) Lakoff \& Johnson incapsulate our major criticism of the way metaphor is dealt with in traditional terminology theory:

metaphor is typically viewed as characteristic of language alone, a matter of words rather than thought or action. (3)

We have found traces of the implicit (Felber 1984) and the explicit (ISO TC 37) belief that for traditional terminology theory, metaphor is only relevant as an aspect of language's naming capacity. Felber (1984) does not use the term metaphor but does mention "borrowings from the same language" (175) when discussing "terms".

Sometimes it proves to be useful to attribute a modified meaning to a term current in another subject field provided this field is sufficiently remote to avoid ambiguity. Such a term is called transferred term [sic]. (175)

One of Felber's examples is: "the terms "information" and "code" were introduced in genetics with modified meanings" (175). Felber does not comment on the role the interpretation or understanding of genetics in terms of "information" and "code" played in the creative aspect of scientific thinking. In his analysis the thinking and understanding had been accomplished before a term was allocated. The reason why - according to Felber - this "term based on transfer" is assigned to the concept and not a different "literal term" is that "a skilfully chosen transferred term may be more concise than a specially constructed complex term" (175). The word metaphor is not even mentioned by Felber. For him the transferred term is only of importance for the naming of a concept which ideally happens independently of the understanding of the concept for the sake of avoidance of polysemy (see Temmerman 2000a, chapter 3). The concept itself - traditional terminologists like Felber believe - comes about independently of language. He believes this is the case because the concept should exist in a clear-cut, objective way, being part of the one and only real world. At the same time the transfer element is considered to be only part of language in its naming capacity. In this article we will show how the information-model was at the basis of a new understanding of genetics. A list of lexicalisations were the result of understanding via this $\mathrm{CM}$. 
In contrast, the term "metaphor" does occur in ISO/TC 37/SC1/cd $704.2 \mathrm{~N} 13395 \mathrm{EN}$. It is defined as a term formation method in interdisciplinary borrowing.

In interdisciplinary borrowing, a word from general language or a term from another subject field is borrowed and assigned a new concept. (26)

The examples given are: "memory (capacity of the human brain); memory (temporary storage capacity of a computer)" and "mouse (small rodent); mouse (computer/operator interface device)." Even though the ISO/TC37 standard points out that "Interdisciplinary borrowing utilizes individual characteristics of the original concept (or meaning) in a metaphorical manner, which is a source of polysemy in both general and special language" (26), it does not offer principles for a systematic description of metaphor in a particular domain. Suggestions on how to study and describe metaphor in a systematic way are given by Lakoff \& Johnson (1980) and Lakoff (1987). Unlike adherents of objectivist traditional terminology theory, who believe that special language communication can benefit from ruling out metaphor, these linguists claim that metaphor is pervasive in every aspect of understanding, not just in language but also in thought and action. "Our ordinary conceptual system, in terms of which we both think and act, is fundamentally metaphorical in nature." (3) Based on their suggestions for analysis and description of metaphor, we offer an alternative interpretation for the occurrence of the terms information and code (see section 3.1.) in genetics. These terms were not just "introduced in genetics with modified meanings" (Felber 1984:175). They are the result of understanding and naming on the basis of a "Metaphoric Idealised Cognitive Model" (m-ICM) (Lakoff 1987) which ushered in the new understanding of genetics as information. Lakoff's (1987) main thesis is "that we organize our knowledge by means of structures called idealized cognitive models or ICMs, and that category structures and prototype effects are by-products of that organization" (68).

According to experientialist theory metaphorisation is achieved by partial mapping of some ICM structure in a source domain onto a corresponding structure in a target domain. For easy reference we shall distinguish between, on the one hand, the primary (or source) domain (which can be literal or metaphorical) and, on the other, the secondary (or target) metaphoric domain.

The information m-ICM has (at least) four sub-m-ICMs which show in several metaphorical namings: sub-m-ICM one: GENETIC MATERIAL (DNA) IS A LANGUAGE, sub-m-ICM two: THE TOTALITY OF THE GENETIC MATERIAL (THE GENOME) OF AN ORGANISM IS AN ATLAS OF MAPS, sub-m-ICM three: GENETIC MATERIAL (DNA) IS THE SOFTWARE OF THE CELL, sub-m-ICM four: GENETIC MATERIAL IS A FILM-TAPE.

As our conceptual system is not something we are constantly consciously aware of, one way to find the m-ICMs which structure part of our understanding is to look for their traces in language (parole). 


\section{Metaphorical naming: the traces in language of $\mathrm{m}-\mathrm{ICMs}$}

In this section we want to concentrate on the growth of understanding and knowledge through metaphorical reasoning (the mapping of a source domain onto a target domain). Metaphorical reasoning results in the understanding of a new fact, situation, process, or whatever type of category, based on the imagined analogy between what one is trying to come to grips with, to understand, with something one knows and understands already. This inventive or creative capacity is made tangible and leaves its traces in neolexicalisations. The imaginative reasoning of which the metaphorical naming of new categories with existing lexemes is the result, is rooted in human experience.

Underlying the progress in the understanding of the mechanisms of life are a number of analogies which have left their traces in metaphorical lexicalisations. One can witness the development of a new lexical field based on specific metaphorical gestalt structures or analogy image schemata. When studying the mapping not just at the lexeme level but also at the structural level of categories and domains (see Temmerman 2000a) the mechanisms of metaphorical reasoning are revealed.

The domain metaphor underlying the understanding of molecular genetics is that heredity is based on information stored in our genes (DNA). We quote one text fragment which states this explicitly²:

The flow of genetic information is unidirectional, from DNA to protein with messenger RNA (mRNA) as an intermediate. The copying of DNA-encoded genetic information into RNA is known as transcription with the further conversion into protein being termed translation. This concept of information flow is known as the Central Dogma. (Nicholl 1994:8)

Several sub-domains of the domain m-ICM around information are expanded upon and are the explanation for a number of metaphorical lexicalisations like:

- DNA IS A LANGUAGE. Genes are messages written in a language. This is a first sub-m-ICM based on the experience that information is often expressed in a language (section 3.1.).

- DNA IS AN ATLAS OF MAPS. The totality of the localisation of genetic information of an organism (the genome) can be depicted on maps. Just like explorers of the globe depicted information on the localisation of geographical phenomena they had been able to observe on maps, geneticists mark the position of genes on genetic maps (section 3.2.).

- DNA IS SOFTWARE. DNA is software which can be run by the cell. This is a third sub-m-ICM based on the experience that information is often stored and made available in an electronic format (section 3.3.).

- DNA IS A FILM. DNA is a film which can be 'read' by a projector. This is a fourth sub-m-ICM based on the experience that informa- 
tion can be stored and made available on film-tapes (see section 3.4.).

\subsection{DNA IS A LANGUAGE}

A first sub-ICM is based on the experience that information is often expressed in language. In this case the genetic material (the DNA) can be understood as if it was a language. Shapiro (1991:4) describes how the idea that our genetic plan is stored in letters has been around for a little more than a generation. Before that, our ancestors were inspired by other imagined analogies which left their traces in language. Remnants of a much older idea are still preserved in language as a type of verbal fossil: that heredity is preserved and transmitted by our blood. The thought has become so familiar that we do not even pause when we see such phrases as royal blood, bad blood, blood relative, blue blood, and mixed blood. The blood theory was first devised by Aristotle (384-322 BC) and others of that era. For those who believed this idea, inheritance involved a blending of parental qualities, as in the mixture of two different liquids.

Linear text is different. It can be spliced but not blended. The child receives a selection of components from both parents. Some remain intact, while other traits from a parent may be lost entirely.

We summarise the story of inheritance and indicate in bold face the lexicalisations which bear on the underlying language analogy. The summary is based on Hodson (1992) and Berg \& Singer (1992).

The mechanisms of inheritance were discovered in 1866 by Gregor Mendel. For Mendel the 'factors' of inheritance (we now call them genes) were entirely abstract entities. Microscopes were by that time operating at magnifications of $1000 \mathrm{x}$ or more. In the cell nucleus structures that looked like coloured threads were seen; they were named chromosomes (from the Greek for 'coloured bodies'). It was immediately realised that here was the reality behind Mendel's 'factors'. Chromosome research became the focus of genetics. It was obvious that the chromosomes provided the physical basis for Mendel's mechanisms of inheritance; they could not be the same as Mendel's factors (genes) for the simple reason that there were not enough of them.

Although the behaviour of genes was becoming better and better understood, there was no information about their physical behaviour beyond the fact that they were located in a row along the chromosomes. It was clear that the genes were in some way carrying messages, and that in order to be self-perpetuating through cell divisions, the genes must be able to duplicate themselves accurately. But there was no theory about what chromosomes could be made of to give them these remarkable properties. Later experiments pointed out that the secret was in the DNA (deoxyribonucleic acid). Francis Crick and James Watson tackled the problem of DNA's double helical structure by building a scale model of wire and pieces of cardboard. The molecule was like a spiral staircase, with the steps made of pairs of bases 
(A (adenine) always joined to $\mathrm{T}$ (thymine), $\mathrm{C}$ (cytosine) always joined to $\mathrm{G}$ (guanine)) and the banisters made of sugar-phosphate chains.

What Crick and Watson had discovered was that DNA had a structure which allowed it to copy itself. Since A must be paired with T, and C with $\mathrm{G}$, it follows that, if a DNA molecule is split down the middle lengthwise, all the information is there to reconstitute the whole molecule again. Crick and Watson's proposed structure for DNA also provided the explanation for how a gene works, in chemical terms. It was already known that a gene controls the production of a single protein. What the Crick-Watson model showed was how the gene could contain a message encoded in the sequence of letters which was the specification of which protein is to be made. The coding structure of DNA does two things (fig. 1.):

- It ensures that DNA is replicated to produce more DNA.

- It ensures that DNA is transcribed into RNA, which is then translated into protein.

\section{Transcription and translation}

When DNA makes a protein, it does so via an intermediate molecule called ribonucleic acid (RNA) which is very similar to DNA. RNA is usually in the form of a single strand. A molecule of RNA can be made to an exact and repeatable pattern by reading off the base sequence of a stretch of DNA; this process is called transcription. The strand of RNA produced in this way is known as messenger RNA, or mRNA, since it carries the message telling that protein is to be made from the particular stretch of DNA that was copied.

Sydney Brenner worked with Crick on deciphering the DNA code, and they discovered that it is written in 'words' of three letters. As there are four possible bases occurring in groups of three there are 64 (i.e. $4^{3}$ ) possible combinations, but only 20 amino acids to be coded for. It turned out that most amino acids are coded for by more than one codon, and that there are three codons which do not represent any amino acid but are 'stop' signals where the protein-coding message ends (see fig. 4.).

The code sequence of the DNA gene is used to build a molecule of messenger RNA; this is assembled by an enzyme called RNA polymerase, and this part of the process is called transcription.

There are also many molecules of a different kind of RNA known as transfer RNA (tRNA). Each tRNA molecule consists of only three bases. These three bases form an anticodon, and each of these matches on to the codon in the mRNA. This part of the process, known as translation, takes place on the ribosomes, which act as a sort of assembly frame for building proteins. The tRNA molecules form a line, and the amino acids join up in the specified order to form the protein chain. 


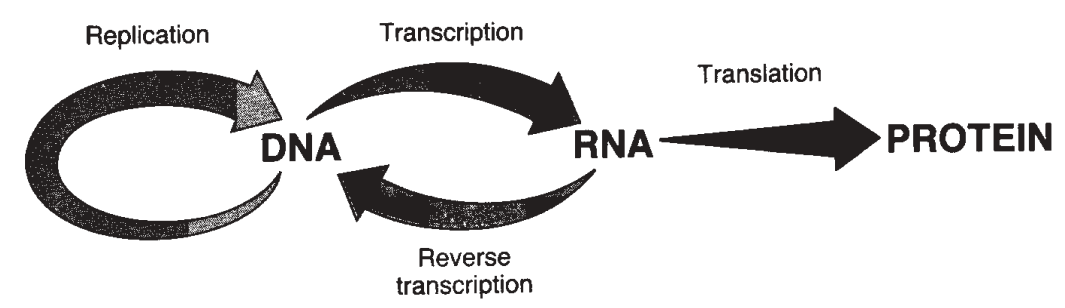

Figure 1: The arrows indicate the processes and directions that pass genetic information from DNA to RNA, from RNA to protein, and from RNA to DNA (Berg \& Singer 1992:35).

It is difficult to figure out whether the cognitive frame or gestalt of 'language' is activated once the analogy between genes and language is understood; or whether one detail of the analogy: the visualisation of bases on the DNA strands, which are abbreviated to the first letters of the bases' names $(A, T, C, G)$, triggered off the understanding of genetic processes via the language analogy. Metaphorical transfer of the understanding of information coded in language to the new understanding and naming of the scientific field of genetics is possible. The language metaphorical model begins to show its impact on thinking about genetics and naming the units of understanding. When dealing with the message in DNA, writers rely on the existing vocabulary of everything which has to do with language and language processing. The analogy is likely to give rise to explicit lexicalisations.

We have to distinguish between a) borrowings of terms from the language source domain model which provides the analogy (e.g. letter); b) creations of terms based on the language source domain model which provides the analogy but using a word which existed already in a different domain (e.g. to sequence); and c) new creations inspired by the language source domain model which provides the analogy but named differently (e.g. codon) (see fig. 2.).

In Temmerman 2000a, chapter 5, we quote several text fragments from our text corpus in which the analogy model is explained.

The metaphorical model does not provide a $100 \%$ analogy. We found two limitations: a) there is lack of full parallelism between units of understanding indicated by the same term in the source and target domains of the metaphorical model, and b) more lexicalisations based on the language analogy were feasible but did not materialize for reasons of competition with other types of lexicalisations. Sometimes the competition stems from other sub-m-ICMs of the information model.

So much for the evidence we came across when trying to find details on the language sub-m-ICM. We shall now switch to the second sub-m-ICM concerning information we distinguished in the textual material on the life sciences. 


\begin{tabular}{|l|l|l|}
\hline & $\begin{array}{l}\text { elements of the language } \\
\text { source domain model which } \\
\text { serve in the analogy }\end{array}$ & $\begin{array}{l}\text { lexicalisations concerning } \\
\text { language-inspired informa- } \\
\text { tion in genes }\end{array}$ \\
\hline $\begin{array}{l}\text { type a } \\
\text { (existing } \\
\text { term or } \\
\text { word is } \\
\text { borrowed) }\end{array}$ & letter & $\begin{array}{l}\text { letter (representing a } \\
\text { base (nucleotide)) }\end{array}$ \\
\hline $\begin{array}{l}\text { type b } \\
\text { (existing } \\
\text { word is } \\
\text { assigned } \\
\text { new sense) }\end{array}$ & $\begin{array}{l}\text { letters occur in a particular } \\
\text { order or sequence in a text }\end{array}$ & $\begin{array}{l}\text { be determined with a } \\
\text { method called sequencing }\end{array}$ \\
\hline $\begin{array}{l}\text { type c } \\
\text { (new term } \\
\text { is created) }\end{array}$ & $\begin{array}{l}\text { words represent units of } \\
\text { information }\end{array}$ & $\begin{array}{l}\text { condons are three letter } \\
\text { words }\end{array}$ \\
\hline
\end{tabular}

Figure 2: Three types of terms finding their origin in the language analogy of genetics.

\subsection{DNA IS INFORMATION IN AN ATLAS OF MAPS}

We first present the information on the analogy between genetic mapping and geographical mapping (Jones uses the term "genetic geography" (1993:46)) and indicate the lexicalisations which can be understood as resulting from this analogy. Then we show how the analogy permits further elaboration without this necessarily giving rise to more terminology. In didactic texts the analogy is further exploited in order to help the reader understand the subject and neo-lexicalisations are created. These neologisms, however, can not be considered real terms.

\subsubsection{Genetic and geographical mapping}

The analogy between the representation of locations and their mutual distances and genes helped one to understand the importance of the position of genes in the genome of organisms. In higher organisms like human beings the information needed is of a double nature: scientists will want to know on the one hand on which chromosome a particular gene is to be found and on the other where in the sequence of genetic information on the DNA strand the particular gene is to be found. Based on the experience that information on previously unknown territory can be obtained and stored by exploring and carefully mapping what one discovers, the way explorers did 
when they were discovering previously unknown continents, geneticists set about mapping the genomes of different organisms. The human genome is "the blueprint for the development of a single fertilized egg into a complex organism of more than $10^{13}$ cells. The blueprint is written in a coded message given by the sequence of nucleotide bases - the As, Cs, Gs and Ts that are strung along the DNA molecules in the genome" (Cooper 1994:71). Anyone who has basic biology knows that DNA contains genes, that genes are the coded messages for making proteins and that proteins carry out all of the functions of an organism. It was considered a good idea to start reading the entire sequence of bases from one end to the other and to draw a complete genetic map of man, defined by RFLPs (restriction fragment length polymorphisms) which are used as marker genes. This resulted in the Human Genome Project, one of the most ambitious scientific programmes of the $20^{\text {th }}$ century. It is an international effort that seeks to create a detailed map of human DNA.

Since the project started (officially in October 1990), several teams from all over the world have been busily mapping the 50,000 to 100,000 human genes and sequencing the base pairs ( 6 billion bases) they consist of (Cooper, 1994:71). By 2005 the maps should be completed. They will be of inestimable value in the development of biotechnology, biological research and clinical medicine, because they will allow the scientists to localise the genes, causing certain hereditary diseases, on the human chromosomes.

A distinction is made between genetic-linkage maps and physical maps. The difference between these two can be summarised as follows: genetic-linkage maps show the position of each gene in relation to another gene; on physical maps one can read the exact number of base pairs between two genes. It is the combination of the genetic-linkage maps and the physical maps that will reveal the human genome.

\begin{tabular}{|l|l|}
\hline $\begin{array}{l}\text { source domain: } \\
\text { geographical map }\end{array}$ & $\begin{array}{l}\text { target domain: } \\
\text { genetic map }\end{array}$ \\
\hline continents & chromosomes \\
\hline to localise places & to localise genes \\
\hline markers or landmarks & RFLPs as markers \\
\hline $\begin{array}{l}\text { relative position of places } \\
\text { (in kilometres or miles) }\end{array}$ & $\begin{array}{l}\text { genetic-linkage map: the position of } \\
\text { each gene in relation to another gene } \\
\text { (genetic distance in centimorgans) } \\
\text { physical map: the number of base } \\
\text { pairs between two genes (distance in } \\
\text { base pairs between landmarks }\end{array}$ \\
\hline region & region \\
\hline site & site \\
\hline
\end{tabular}

Figure 3: Aspects of the analogy between geography maps and genetic maps. 


\subsubsection{Lexicalisations based on the analogy}

We studied fragments from four books written for non-specialists (Jones 1993; Levine \& Suzuki 1993; Cooper 1994 and Shapiro 1991), in which the aspects of this analogy shown in fig. 3 are worked out in more detail (see Temmerman 2000a, chapter 5). We could observe the following phenomena:

a) The analogy has given rise to generally accepted vocabulary: map, mapping, landmarks, sites (what we called type a naming in section 3.1.).

b) The analogy has given rise to lexicalisations which are adapted to the specificity of the new field under development (what we called type b naming in section 3.1.). Examples are genetic mapping like genetic linkage mapping and physical mapping

c) The analogy gives rise to didactic metaphorisations (discovery, tracking down, gene hunters, explorers.

d) We also find examples of how authors elaborate aspects of the analogy to make the information pass, but without further lexicalisations resulting from this e.g.

That work is important, because in many ways, finding a gene in the human genome is like trying to track down an individual person with no information other than the fact that the target is located somewhere on earth. (Levine \& Suzuki 1993:28)

Without YACs, we would have been stuck with little pieces of the physical map and no way to put them together. To use an analogy, we would have had an interstate highway that was interrupted every mile or so by a stretch of dirt road or no road at all. That's better than nothing, but it's not as useful or efficient as a continuous highway." (Cooper 1994:103)

But maps are not merely navigational tools. They also provide a means of correlating many types of data. For example, we use maps to locate mountains, rivers, and city and state boundaries, but we also use maps to plot population density, average rainfall, climate changes, earthquake activity, and so on. And once we plot those data on a map we start to see relationships. Cytogeneticists, doctors, and molecular biologists are all making observations on the genomes of individuals on a daily basis, but without a map we have no way of correlating those data with other information about the genome. Once we have a continuous contig map, those data will become important. (Cooper 1994:104-5)

e) We find extra information which is loosely linked to the analogy by implication. The analogy between explorers who are drawers of maps in territories where they have to live with uncertainties and "gene explorers are pushing forward into vast uncharted territory in the face of great uncertainties - both political and technological." (Cooper 1994:70) 


\subsection{DNA IS SOFTWARE}

The third information sub-m-ICM involves genetic material (DNA) being understood as the software in an information processing system (the cell). This is explicitly pointed out in:

There's another appropriate analogy here, one that emphasizes why the unity of life has been so important to molecular biology. You can think of DNA's coded instructions as molecular "software" that runs the "hardware" of life. $\underline{\text { Just }^{2} \mathrm{~s}^{3}}$ a word-processing program tells computer hardware what to do, DNA's instructions control life's machinery. Why is that comparison useful? Because if you work with computers the way most of us do, you know enough about your favorite word processor or spreadsheet to use it, but you could hardly write the program yourself. In much the same manner, molecular biologists know enough about certain DNA-based "programs" to use them without fully understanding how they work.

So it's handy that much of the life's software - regardless of the organism it comes from - will run on the hardware of nearly any other living cell. That's why, for example, researchers who discover and learn to control the molecular word processor used by one organism can harness that tool to manipulate genetic text in different organisms without having to learn precisely why or how that particular molecular program works as it does. (Levine \& Suzuki 1993:23)

As pointed out above, the subunits of the DNA strands, the nucleotides, are the chemical basis for storage of information in DNA. (Drlica 1992:33)

"DNA's coded instructions" are thought of as "molecular software that runs the hardware of life". The comparison is relevant because just like computer users can use but not write a program, molecular biologists know enough about DNA to use it without fully understanding how it works. The 'software' (DNA) of a particular organism can be run on the hardware (cells) of nearly any other organism.

\subsection{DNA IS A TAPE OF FILM}

Potentially, the information model consists of more sub-models than the three we indicated so far (language, geography, computer software). In Drlica (1984 \& 1992) we find that a fourth information sub-m-ICM, the film sub-m-ICM (fig. 4.), is brought to the fore to explain the structure of genetic information.

In some ways DNA is similar to motion picture film. Like film, DNA is subdivided into "frames" that make sense when seen in the correct order. In DNA the "frames" correspond to the letters in the genetic code, [...]. When a number of frames or genetic letters are organized into a specific combination, they create a scene in the case of film and a gene in the case of DNA. (Drlica 1992:4)

As pointed out above, the subunits of the DNA strands, the nucleotides, are the chemical basis for storage of information in DNA. Returning to the film analogy [...], the units we have now defined as nucleotide pairs, or base pairs, correspond to a scene in the motion picture film. (Drlica 1992:34) 


\begin{tabular}{|l|l|}
\hline motion picture film & DNA \\
\hline Frames & letters in the genetic code \\
\hline Scenes & genes \\
\hline
\end{tabular}

Figure 4: The analogy between motion picture film and DNA.

The lexicalisations frames and scenes are ideolectical lexicalisations, which are used here for didactic purposes. These lexicalisations are transient. The lexemes do not become terms in the language of the biological sciences. In Drlica's book this analogy reinforces the understanding of gene splicing. Genes can be spliced in the laboratory the way film or tape can be spliced in a studio. For splicing we refer to Temmerman (1995) and Temmerman (1998).

\section{Towards guidelines for the description of metaphorical models}

Traditional terminology theory adheres to an objectivist model of reality. At the basis is the belief that there is an objective world out there which has to be studied in an objective way. Traditional terminology theory believes that language has to be controlled (i.e. standardised) in order to secure objectivity, clear-cut understanding, and efficiency. For that reason it is claimed that literal lexicalisations are preferable to metaphorisations. We have pointed out non-objectivist models of understanding in the special language of the life sciences in which language and thought appear to be based on experience and, more importantly, in which language seemed to play a role in analogical thinking resulting in metaphorisations.

We have given examples of the fact that the naming of new units of understanding is not arbitrary but motivated. The role of metaphorical models in the progress of knowledge is reflected in the naming of new units of understanding. New findings often appear to be the result of a deviant, alternative approach, which calls for imaginative creativity. Metaphorical thinking is part of the mechanisms which stimulate the imagination.

We have proved the existence of the information metaphorical model in the coherent and related naming of a number of new units of understanding in the life sciences.

The discipline of terminology theory should work out guidelines for the description of metaphorical models (ontologies) in order to help terminologists incorporate this aspect of relatedness between terms in terminological databases.

\section{The impact for scientific translators training}

The insight that metaphorical neolexicalisation in science can be part and parcel of the progress of a discipline has its implications for the methodolo- 
gy in scientific translators training. In the first place translators should be aware of the distinction between creative and didactic metaphors. They should learn to distinguish between metaphorical neolexicalisations which are introduced by researchers as part of the progress in creative scientific understanding and occasional didactic metaphors which are introduced by writers of popularising, less specialised texts on the same subject. In the second place scientific translators (and probably other translators in specialised disciplines as well) should - ideally - have been introduced to the theory of metaphorical models underlying human categorisation and understanding (Lakoff 1987).

If both conditions are met translators will know how to make an analysis of each case of metaphorical lexicalisation they come across and they will be in a position to find the best equivalents in the target language. The insight in metaphorical CMs will widen their "discursive autonomy" (Dancette 1995), i.e. help them to grasp the subject matter to the point of being able to explain it in one's own words. Most importantly, metaphorical models exist in a language-independent way. The information CM which is at the basis of understanding the essence of life in the life sciences can be expressed in any natural language having words to refer to all categories related to the information-related subdomains, be it "DNA is a language", "DNA is an atlas of maps", "DNA is software", or "DNA is a tape of film". Understanding this metaphorical model will give the translator the confidence to express the information he gathers from the source text in language A in a target text in language B (Temmerman 2000,b).

\section{Bibliography}

Berg, P. \& M. Singer (1992). The Language of Heredity. California: Blackwell Scientific Publications.

Boyd, R. (1979). "Metaphor and Theory Change." A. Ortony (ed.) (1979). Metaphor and Thought. London/New York: CUP.

Cooper, N. (1994). The Human Genome Project. California: University Science books.

Dancette, J. (1995). Parcours de traduction, étude expérimentale du processus de compréhension. Lille: Presses Universitaires de Lille.

Drlica, K. (1984). Understanding DNA and Gene Cloning. New York: John Willey and Sons.

Drlica, K. ( $\left.{ }^{2} 1992\right)$. Understanding DNA and Gene Cloning. New York: John Willey and Sons.

Felber, H. (1984). Terminology Manual. Vienna: Infoterm.

Gentner, D. et al. (1988). "Viewing Metaphor as Analogy." D. Helman (ed.) (1988). Analogical Reasoning. Kluwer Academic Publications, 171-177.

Hodson, A. (1992). Essential Genetics. London: Bloomsbury.

Indurkhya, B. (1992). Metaphor and Cognition. Studies in Cognitive Systems. Dordrecht: Kluwer Academic Publishers.

ISO/TC 37/ SC 1/CD 704.2 N 13395 EN.(1995). Terminology Work - Principles and Methods.

Jones, G. ( 1993). “The Quiet Genius who Decoded Life.” New Scientist, Oct. 8, 32-35. 
Johnson, M. (1987). The Body in the Mind. Chicago and London: The University of Chicago Press.

Kittay, E. (1987). Metaphor. Its Cognitive Force and Linguistic Structure. Oxford: Clarendon.

Lakoff, G. \& M. Johnson (1980). Metaphors we Live By. Chicago: University of Chicago Press.

Lakoff, G. (1987). Women, Fire and Dangerous Things. Chicago: University of Chicago Press.

Levine, J. \& D. Suzuki (1993). The Secret of Life. Boston: WGBH Educational Foundation.

Liebert, W.-A. (1992). Metaphernbereiche der deutschen Alltagssprache. Frankfurt am Main: Peter Lang.

Liebert, W.-A. (1995a). "Metaphernbereiche der virologischen Aidsforschung." Lexicology 1(1),142-82.

Liebert, W.-A. (1995b). "The Lexicon of metaphor models as a mental tool for analogical problem solving in science." R. Dirven \& J. Vanparijs (eds) (1995). Current approaches to the lexicon. Frankfurt/M: Peter Lang.

Liebert, W.-A. (1996). "Die transdiskursive Vorstellungswelt zum Aids-Virus. Heterogenität und Einheit von Textsorten im Übergang von Fachlichkeit und Nichtfachlichkeit." H. Kalverkämper \& K.-D. Baumann (eds) (1996). Fachliche Textsorten. Tübingen: Gunter Narr Verlag.

Montgomery, S. (2000). Science in Translation. Chicago \& London: University of Chicago Press.

Nicholl, D. (1994). An Introduction to Genetic Engineering. Cambridge: Cambridge University Press.

Ortony, A. (ed.) (1979). Metaphor and Thought. London/New York: CUP.

Paprotté, W. \& R. Dirven (1985). The Ubiquity of Metaphor. Amsterdam: John Benjamin.

Pavel, S. (1993). "Neology and Phraseology as Terminology-in-the-Making." H. Sonneveld \& K. Loening (eds) (1993). Terminology. Applications in Interdisciplinary Communication. Amsterdam: John Benjamins, 21-34.

Shapiro, R. (1991). The Human Blueprint: the Race to Unlock the Secrets of our Genetic Scpt. New York: St. Martin's Press.

Temmerman, R. (1995). "The Process of Revitalisation of Old Words: "Splicing", a case study in the extension of reference." Terminology 2 (1), 107-128.

Temmerman, R. (1998). Terminology Beyond Standardisation. Language and Categorisation in the Life Sciences. PhD dissertation. Katholieke Universiteit Leuven

Temmerman, R. (2000a). Towards New Ways in Terminology Description. The Sociocognitive Approach. Amsterdam/Philadelphia: John Benjamins.

Temmerman, R. (2000b). "Une théorie réaliste de la terminologie: le sociocognitivisme." Terminologie Nouvelles 21, 58-64.

Way, E. C. (1991). Knowledge Representation and Metaphor. Dordrecht: Kluwer Academic Publishers.

Wills, C. (1991). Exons, Introns and Talking Gene. New York: Harper Collins.

\footnotetext{
${ }^{1}$ The Saussurian principle of the arbitrary character of linguistic signs concerned the absence of motivated links between sound and concept. Yet, "The arbitrariness of the linguistic sign and the systematic character of phonology notwithstanding, the meaning of linguistic utterances still derives from the meaning of their components, the words." (Pavel 1989:29). Experientialism tries to find new explanations for motivated naming.
} 
${ }^{2}$ We could quote scores of texts in which the information analogy is explicitly stated. The basic analogy is very much alive and still actively serving as a source for new lexicalisations in the course of further discoveries and better understanding as we shall see.

${ }^{3}$ The underlining is ours. 